\title{
Ewing's Sarcoma of the Mandible in a Young Child
}

\author{
Marco Túllio BRAZÃO-SILVA ${ }^{1}$ \\ Alexandre Vieira FERNANDES ${ }^{2}$ \\ Paulo Rogério de FARIA ${ }^{3}$ \\ Sérgio Vitorino CARDOSO ${ }^{3}$ \\ Adriano Mota LOYOLA ${ }^{3}$
}

\author{
${ }^{1}$ Department of General Pathology, Triângulo Mineiro Federal University, Uberaba, MG, Brazil \\ ${ }^{2}$ Department of Oral Surgery, Interactive Institute of Dental Qualification, Uberlândia, MG, Brazil \\ ${ }^{3}$ Department of Oral Pathology, Dental School, Federal University of Uberlândia, Uberlândia, MG, Brazil
}

\begin{abstract}
Ewing's sarcoma (ES) is a malignancy primarily affecting bone tissue that is commonly diagnosed in adolescents and young adults. Its occurrence in the head and neck region is unusual and generally involves the mandible and maxilla. An extensive review of the literature shows only few cases of the oral ES in patients under the age of 5. This paper reports a rare case of ES of the mandible in a 4-year-old girl, which had been previously misdiagnosed and treated as a dental abscess. In the clinical examination, a hard immobile expansive mass of $5 \mathrm{~cm}$ in diameter was observed on the left side of the mandible. Radiographic examination revealed a radiolucent lesion with ill-defined borders and wide vestibular bone plate destruction. Microscopically, the tumor was composed by monotonous small round cells that exhibited immunoreactivity for CD99, vimentin and pancytokeratin. The patient was subjected to multiagent chemotherapy with ifosfamide, carboplatin, etoposide, vincristine, cyclophosfamide and doxorrubycin (VAC/ICE regimen). However, after the first chemotherapeutic cycle, the patient died due to disseminated infection. This case elucidates the importance of professional knowledge of the relevant aspects of malignant lesions such as ES.
\end{abstract}

Key Word: Ewing's sarcoma, mandible, child, diagnosis, immunohistochemistry.

\section{INTRODUCTION}

Ewing's sarcoma (ES) is a rare malignant small round cell tumor that primarily affects the skeletal system (1). It accounts for 4 to $10 \%$ of all types of bone cancer, with long bones and pelvis being the most common locations $(1,2)$. It affects mainly adolescents and young adults and is rarely seen before the age of 5 and after age of 30. Clinically, this tumor has an aggressive behavior characterized by rapid growth and high probability of micrometastasis at diagnosis (3).

The occurrence of ES in the head and neck region is unusual and, when it occurs, it generally involves the mandible and less frequently the maxilla $(4,5)$. An extensive review of the literature shows only few cases of ES affecting children under 5 years of age. This paper reports a rare case of ES of the mandible in a 4-yearold girl, which had been previously misdiagnosed and treated as a dental abscess.

\section{CASE REPORT}

A 4-year-old white girl was brought to our Department of Oral Pathology with a 1-month history of a painful, progressively enlarging swelling in the left mandible accompanied by relapsing fever at night, which had previously been treated as a dental abscess by a dental practitioner. On clinical examination, a hard fixed expansive mass of approximately $5 \mathrm{~cm}$ in diameter was observed on the left side of the mandible (Fig. 1A). Intraoral examination revealed an expansive mass growing mainly against the vestibular plate of the mandible. The overlying mucosa was centrally erythematous, and no ulceration was noted. On palpation, the mass was hard in consistency and nontender. Displacement of the first and the second deciduous molars into the lingual aspect of the mandible and exposure of dental germ of the first premolar were observed as well (Fig. 1B). On physical examination, the patient was healthy and no 
cervical lymph node was palpable.

The panoramic radiograph disclosed a mixed radiolucent and radiopaque lesion exhibiting ill-defined borders on the right body of the mandible (Fig. 2A). A severe displacement of dental germ of the canine into the base of the mandible was also observed. To more accurately depict the lesion, a computed tomography (CT) scan including a three-dimensional CT scan was performed (Fig. 2B and 2C). It showed a marrowdestroying mass of approximately $3.5 \times 2.3 \mathrm{~cm}$ of size associated with wide vestibular plate destruction of the right ramus of the mandible. A hypothesis of malignant tumor was postulated.

From this, the patient underwent an incisional biopsy and the material was sent to the pathologist for histopathological analysis. Microscopically, the specimens showed solid sheets of small-round cell population scattered in a fibrovascular stroma interposed by fibrous septa. Most of the individual cells exhibited scant cytoplasm, round and oval hypercromatic nuclei and inconspicuous nucleoli (Fig. 3A). Neither mitotic figures nor necrotic areas were seen. Intracytoplasmic glycogen was demonstrated by PAS stain after diastase pretreatment. An immunohistochemical study using a standard avidin-biotin-peroxidase complex technique (DAKO; Carpinteria, CA, USA) was performed and revealed positivity for CD99 (Fig. 3B), vimentin and pancytokeratin. Other immunomarkers were all negative (Table 1). Histopathological and immunohistochemical findings supported the diagnosis of ES.

After diagnosis, a whole body bone scan as well as a bone marrow aspiration biopsy was made and no abnormalities were found. The patient started the treatment with multiagent chemotherapy including ifosfamide, carboplatin, and etoposide as well as vincristine, cyclophosfamide and doxorrubycin (ICE/VAC regimen). However, after the first chemotherapeutic cycle, the patient developed fever, neutropenia, peritonitis, and posteriorly sepses, which was unsuccessfully treated with systemic antibiotic therapy. A few days later her systemic condition deteriorated rapidly that culminated with her death.

\section{DISCUSSION}

ES is a malignant neoplasm that primarily affects long bones of the extremities with nearly $50 \%$ of reported cases involving the femur and pelvis (2). It exhibits a marked predilection for whites and is rarely seen among blacks (3). The majority of the patients affected are between the ages 5 and 20, whereas the disease is distinctly uncommon in individuals before age 5 and after age $30(3,6)$.

ES arising from the bones of the head and neck region is exceedingly uncommon. When it occurs in the jaw, mandible is more frequently affected than the maxilla (5). Cases of ES of the jaws in patients before age 5 are even rarer and a review of the English literature
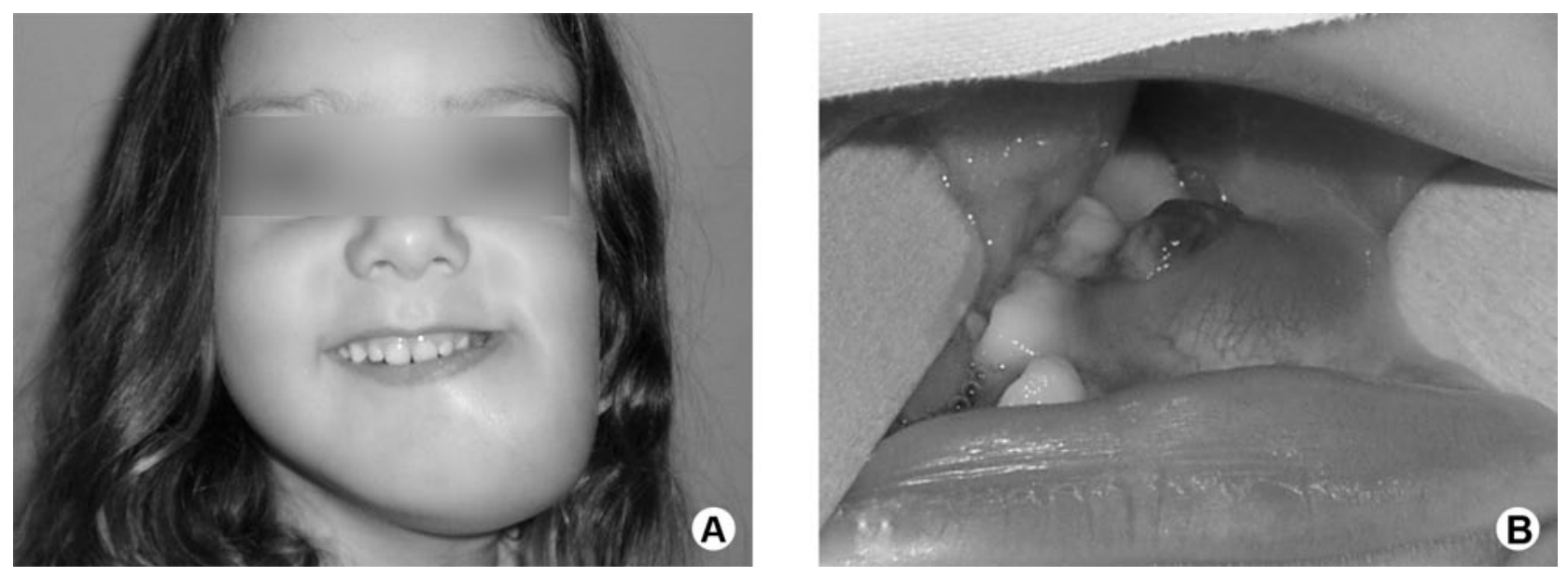

Figure 1. (A) Extra-oral presentation of tumor, showing significant increase in angle of left mandible. (B) Intraoral aspect of the tumor, showing a tender and swollen erythematous mass on the mucosa in the molar region of the left mandible, involving the alveolar ridge and oral mucosa. Note the dental germ being expelled on the surface. 

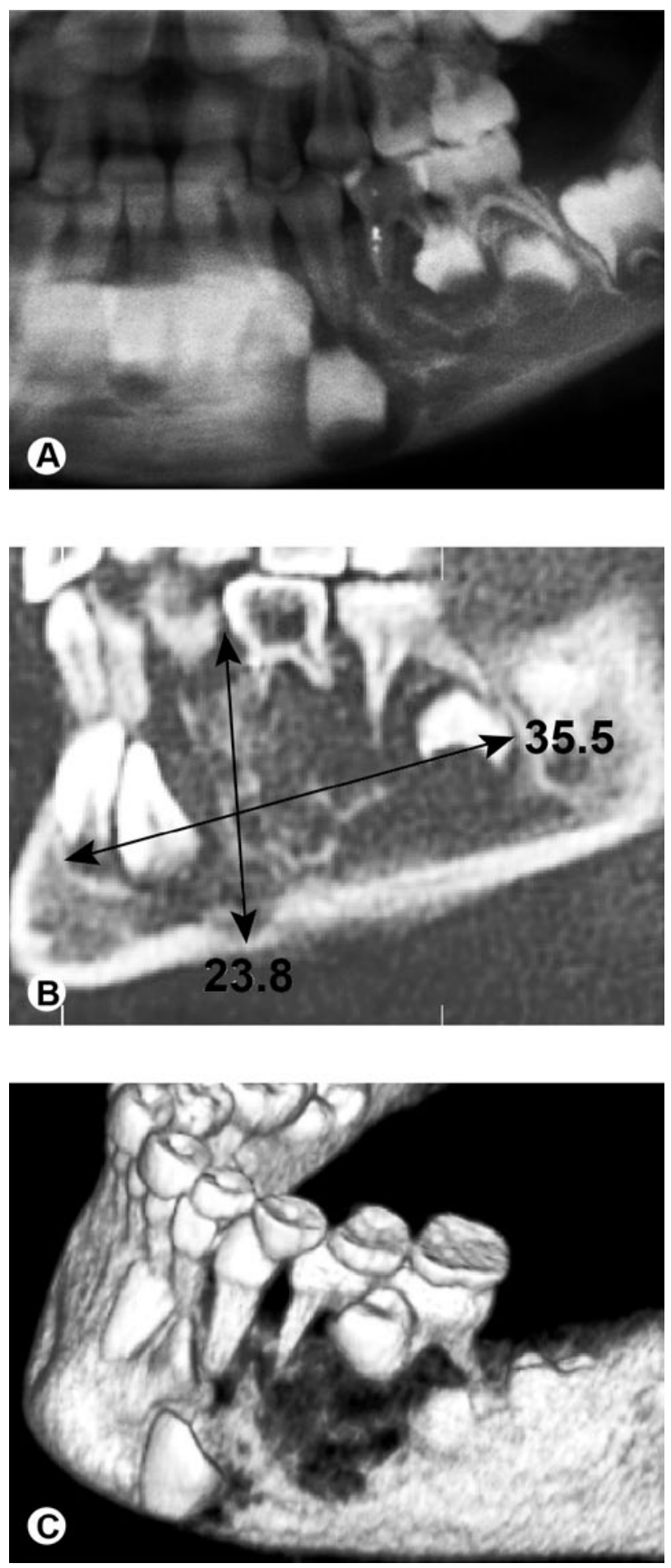

Figure 2. Radiographic and tomographic imaging analysis of the case. (A) Panoramic radiograph showing an osteolytic radiolucent and radiopaque lesion with ill-defined limits, involving the body of left mandible. (B) CT scan showing an extensive osteolytic lesion associated with dental germs floating inside. (C) 3-D CT scan of the mandibular lesion evidencing the irregular pattern of the tumor invasion. we could find out only 2 reported cases. Therefore, the present report aggregates in the literature one additional case of ES of the mandible in a 4-year-old child.

In the head neck region there are nonspecific clinical findings for ES, although most of the patients' complaints at time presentation are commonly associated with mass effect of the tumor and include rapid growth, swelling of the affected area and pain $(7,8)$. In addition, when this tumor arises in the mandible other signs and symptoms, such as loosening teeth, otitis media, and paresthesia, may be also observed (9). Systemic symptoms such as fever, often remittent, about $38^{\circ} \mathrm{C}$, weight loss, and anemia are observed among various patients (10). The present case exhibited clinical aspects similar to those reported in the literature for cases in the head and neck region: it was located in the mandible, displayed a rapidly progressive growth and was accompanied by pain and fever. This presentation is not specific, but it demands complementary exams that can avoid larger arrears in the diagnosis, which in the casuistry of Widhe and Widhe (11), occurred within 5 weeks on the average, harming the precocious diagnosis and leading to the risk of more aggressive approaches.

Table 1. Summary of the immunohistochemical analysis.

\begin{tabular}{lcccc}
\hline Antibodies & Clone & Source & Dilution & Score \\
\hline CD99 & 12E7 & DAKO & $1: 600$ & + \\
vimentin & V9 & DAKO & $1: 2000$ & + \\
pancytokeratin & AE1/AE3 & DAKO & $1: 400$ & + \\
S100 protein & & DAKO & $1: 12000$ & - \\
CD45RO & UCAL-1 & DAKO & $1: 1000$ & - \\
CD45RB & PD7/26 & DAKO & $1: 6000$ & - \\
CD20 & L26 & DAKO & $1: 1200$ & - \\
Desmin & D33 & DAKO & $1: 2000$ & - \\
Chromogranin & DAK-A3 & DAKO & $1: 1000$ & - \\
EMA & E29 & DAKO & $1: 400$ & - \\
Enolase & BBS-NC- & DAKO & $1: 2000$ & - \\
Anti- & VI-H14 & & & - \\
melanosome & HMB-45 & DAKO & $1: 200$ & - \\
PAS & ER-PR8 & DAKO & $1: 120.000$ & - \\
Actin & HHF-35 & DAKO & $1: 2000$ & - \\
\hline
\end{tabular}


Radiographically, ES appears as a poorly defined osteolytic lesion that may be frequently associated with cortical erosion and soft tissue mass adjacent to the destructive site $(6,12)$. Although ES is most often seen presenting osteolytic change with bone destruction, this aspect is not a pathognomonic feature, as other lesions can have the same image pattern, such as neuroblastoma, osteogenic sarcoma, histiocytosis $\mathrm{X}$, and osteomyelitis $(5,13)$. The presence of sun-ray spicules of periosteal bone and displacement or destruction of unerupted tooth follicles have been described as the commonest radiological features for ES affecting jaw bones $(7,13)$. Further, the presence of the laminar periosteal response (known as "onion skin" reaction), which some authors point out as a common radiological feature described for lots of ES of the long bones, is rarely seen in jaws lesions $(6,14)$. In the present case, the radiographic finding was an osteolytic lesion associated with severe displacement of dental germ of the canine and punctual cortical erosion in the base of the mandible. Neither sun-ray spicules of periosteal bone nor an "onion skin reaction" of bone cortical were observed.

Although conventional radiography is still considered an useful method for determining the presence of bone lesions and, of course, an important imaging approach for suggesting ES, CT scan and magnetic resonance imaging have been currently stated by some authors as the best imaging methods for evaluating the full extent of the primary lesion into the soft tissue and bone invasion prior to the onset of therapy $(3,6,14)$. In this case, the CT scan was made before treatment and revealed both the intraosseous origin of the tumor as well as the real extent of bone destruction of the mandible, which was accurately depicted with the threedimensional CT scan imaging method.

Histopathologically, ES is composed of small, poorly differentiated cells with medium-size, round or oval nuclei exhibiting a fine chromatin pattern, small nucleoli and scanty cytoplasm $(6,15)$. The intracytoplasmatic glycogen may be demonstrated by PAS stain in $75 \%$ of the cases, but it is not pathognomonic and conclusive because other small round cell may show the presence of glycogen as well $(14,15)$. Due to similarity with many malignant tumors, the diagnosis of ES can be very difficult and the lesion must be differentiated from other small round cell tumors, such as small cell osteosarcoma, mesenchymal chondrosarcoma, embryonal rhabydomyosarcoma, neuroblastoma and lymphoma $(1,16)$. The use of immunohistochemistry has helped in the diagnosis of this tumor. In general, the tumor cells are positive for vimentin and CD99 and negative for neural, skeletal, vascular and lymphoid cell markers $(3,4)$. Regarding Mic-2 antigen, recently published data have confirmed the high sensitivity of the Mic-2 gene product (CD99) for all ES family tumors with over 95\% of the cases showing positivity for this marker $(4,15)$.
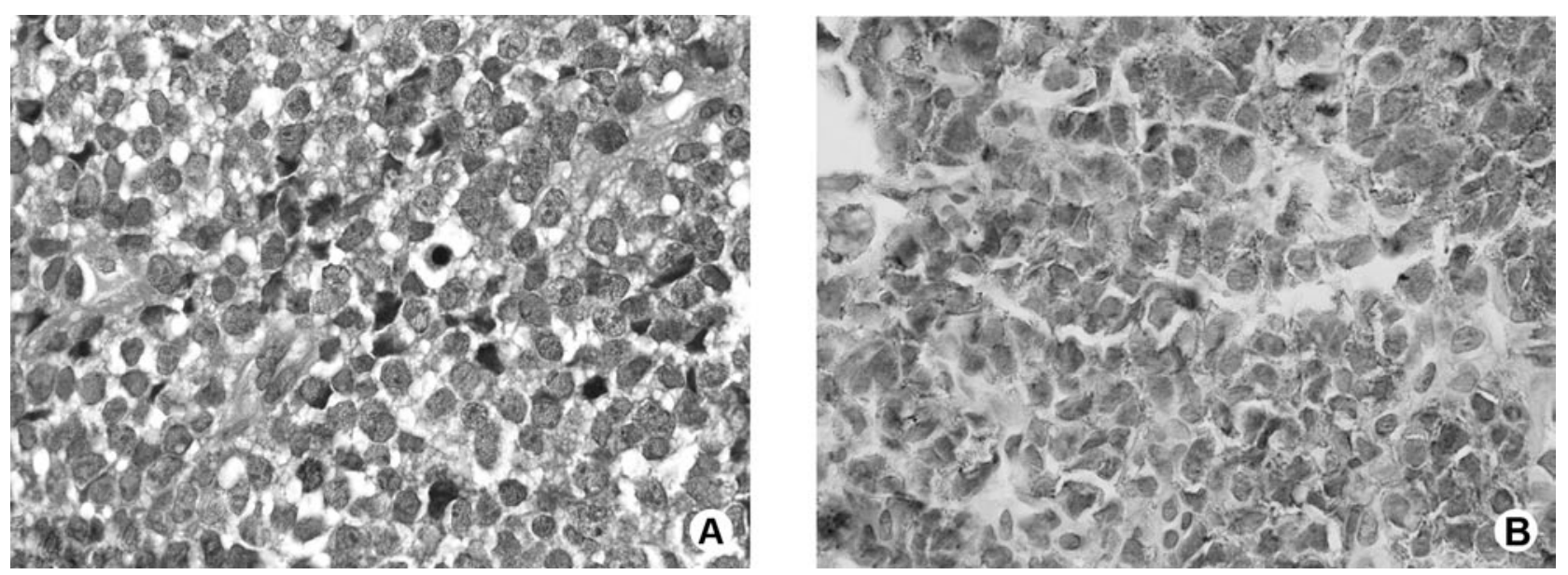

Figure 3. (A) Photomicrograph (HE staining) showing a monotonous population of small round cells with hyperchromatic nuclei, inconspicuous nucleoli, and scant cytoplasm. Thin fibrous septa are grouping the cells in lobules. Discreet vesicles compatibles with glycogen presence and mitotic figures can also be seen. (B) Immunohistochemical histology showing a positive diffuse pattern in the cell cytoplasm for CD99. 
In fact the expression of CD99 protein is not conclusive to ES because other round cell tumors, such as Merkel cell carcinoma, small cell osteosarcoma T-lymphoblastic lymphoma poorly differentiated synovial sarcoma may express this marker (17). A panel of reagents should be adequately evaluated together the morphological aspects of hematoxilin-eosin staining to made a conclusive diagnosis. A cytogenetic finding of chromosomal 11:22 translocations has been applied additionally in some cases, but was not performed in the index case because of non-availability. The present case was positive for CD99, vimentin and pancytokeratin and negative for other immunomarkers, leading to a diagnosis of ES.

It has been reported that combined therapy including surgery, radiotherapy and chemotherapy is the best approach for ES (16). The multidisciplinary treatment protocols has dramatically improved the 5-year survival rate of patients with ES from less than $16 \%$ to more than $75 \%$ of cases $(1,5)$. Radiotherapy alone must be undertaken only to treat non-resectable primary tumor or as a neoadjuvant therapy and chemotherapy to suppress potential micrometastasis and reduce the size of the tumor prior to surgery $(16,18)$. The chemotherapeutic agents most commonly used are vincristine, doxorubicin, cyclophosphamide, ifosfamide, and actinomycin-D. Our patient was subjected to the multiagent chemotherapy before surgery because of the size of the primary tumor.

The prognosis of ES is poor because hematogenous spread and lung metastases occur within a few months after diagnosis, although the tumor burden is considered today as an important factor of prognosis $(1,3,19)$. Systemic disease is the most important predictive factor towards disease-free survival followed by the clinical response to chemotherapy. Clinical features such as systemic symptoms, high erythrocyte sedimentation rate, elevated serum lactate dehydrogenase levels and thrombocytosis is related to poor prognosis $(7,15)$. Tumors arising in bone jaws have a better prognosis than those located in long bones (5). In this case, the patient unfortunately died a few days later after the first cycle of chemotherapy developing a deteriorated clinical picture of fever, neutropenia, peritonitis, and sepses. Although we cannot exclude the possibility of causas mortis be due to disseminated hematogenic spreading of the disease, it is probable that her death resulted from a toxicity associated with the treatment.

In summary, the present case is unique because of the patient's age and the exceedingly rapid clinical course of the tumor, which resulted fatal.

\section{RESUMO}

O sarcoma de Ewing é um tumor maligno primário do osso, comumente diagnosticado em adolescentes e adultos jovens. Sua ocorrência na região de cabeça e pescoço não é usual, e geralmente ocorre em maxila ou mandíbula. Após revisão extensiva da literatura, poucos casos foram identificados acometendo pacientes com menos de 5 anos de idade. Nós relatamos um caso raro de SE em uma criança de 4 anos de idade que foi previamente diagnosticada e tratada como abscesso dentoalveolar. Ao exame clínico, uma massa expansiva endurecida e imóvel de $5 \mathrm{~cm}$ de diâmetro foi observada no lado esquerdo da mandíbula. O exame radiográfico mostrou lesão radiolúcida, com bordas mal definidas e ampla destruição da tábua óssea vestibular. Microscopicamente, o tumor era composto por células pequenas e arredondadas que exibiam imunorreatividade para CD99, vimentina e pancitoqueratina. O paciente foi submetido à quimioterapia com ifosfamida, carboplatina, e etoposide além de vincristina, ciclofosfamida e doxorrubicina (regime VAC/IE). Entretanto, após o primeiro ciclo da quimioterapia, o paciente foi a óbito por infecção disseminada. Este caso salienta a importância do conhecimento profissional no diagnóstico de tumores malígnas tais como o SE.

\section{REFERENCES}

1. Vikas PB, Ahmed MBR, Bastian TS, David TP. Ewing`s sarcoma of the maxilla. Indian J Dent Res 2008;19:66-69.

2. Infante-Cossio P, Gutierrez-Perez JL, Garcia-Perla A, NoguerMediavilla M, Gavilan-Carrasco F. Primary Ewing's sarcoma of the maxilla and zygoma: report of a case. J Oral Maxillofac Surg 2005;63:1539-1542.

3. Heare T, Hensley MA, Dell'Orfano S. Bone tumors: osteosarcoma and Ewing's sarcoma. Curr Opin Pediatr 2009;21:365-372.

4. Schultze-Mosgau S, Thorwarth M, Wehrhan F, Holter W, Stachel $\mathrm{KD}$, Grabenbauer G, et al.. Ewing sarcoma of the mandible in a child: interdisciplinary treatment concepts and surgical reconstruction. J Craniofac Surg 2005;16:1140-1146.

5. Lopes SL, Almeida SM, Costa AL, Zanardi VA, Cendes F. Imaging findings of Ewing's sarcoma in the mandible. J Oral Sci 2007;49:167-171.

6. Gorospe L, Fernández-Gil MA, García-Raya P, Royo A, LópezBarea F, García-Miguel. Ewing`s sarcoma of the mandible: radiologic features with emphasis on magnetic appearance. Oral Surg Oral Med Oral Pathol Oral Radiol Endod 2001;91:728-734.

7. Wood RE, Nortje CJ, Hesseling P, Grotepass F. Ewing's tumor of the jaw. Oral Surg Oral Med Oral Pathol 1990;69:120-127.

8. Vaccani JP, Forte V, de Jong AL, Taylor G. Ewing's sarcoma of the head and neck in children. Int J Pediatr Otorhinolaryngol 1999;48:209-216.

9. Khanna G, Sato Y, Smith RJ, Bauman NM, Nerad J. Causes of facial swelling in pediatric patients: correlation of clinical and radiologic findings. Radiographics 2006;26:157-171.

10. Khoury JD. Ewing sarcoma family of tumors. Adv Anat Pathol 2005;12:212-220.

11. Widhe B, Widhe T. Initial symptoms and clinical features in osteosarcoma and Ewing's sarcoma. J Bone Joint Surg Am 2000;82:667-674.

12. Batsakis JG, Mackay B, el-Naggar AK. Ewing's sarcoma and pe- 
ripheral primitive neuroectodermal tumor: an ínterim report. Ann Otol Rhinol Laryngol 1996;105:838-843.

13. Yalcin S, Turoglu HT, Ozdamar S, Sadikoglu Y, Gurbuzer B, Yenici O. Ewing's tumor of the mandible. Oral Surg Oral Med Oral Pathol 1993;76:362-367.

14. Quesada JL, Alcalde JM, Espinosa JM, García-Tapia R. Ewings' sarcoma of the mandible. J Laryngol Otol 2003;117:736-738.

15. Talesb KT, Motamedi MH, Jeihounian M. Ewing's sarcoma of the mandibular condyle: report of a case. J Oral Maxillofac Surg 2003;61:1216-1219.

16. Fonseca AS, Mezzalira R, Crespo AN, Bortoleto AE Jr, Paschoal JR. Ewing's sarcoma of the head and neck. São Paulo Med J 2000;118:198-200.
17. Kang SM, Yoon KH, Choi JB, Eum JW. Extraskeletal ewing`s sarcoma of the hard palate. J Korean Med Sci 2003;20:687-690.

18. van der Woude HJ, Bloem JL, Hogendoorn PC. Preoperative evaluation and monitoring chemotherapy in patients with highgrade osteogenic and Ewing's sarcoma: review of current imaging modalities. Skeletal Radiol 1998;27:57-71.

19. Berk R, Heller A, Heller D, Schwartz S, Klein EA. Ewing's sarcoma of the mandible: a case report. Oral Surg Oral Med Oral Pathol Oral Radiol Endod 1995;79:159-162.

Accepted March 17, 2010 